\section{Malaria myositis}

Muscular pain and weakness are typical presenting features of polymyositis. Our patient's myositic syndrome proved to be the principal feature of falciparum malaria.

A 25-year-old professional football player, born in Ghana but resident in Britain since the age of 11 years, visited his family in Kamase, Ghana in May 1991. Six weeks after arriving in Ghana he developed fever and diarrhoea. These symptoms continued for two weeks. At the local hospital he was treated with two daily injections of chloroquine. He returned to England two days later but still felt unwell and was unable to resume training because of muscle pain, soreness, and fatigue. He was required to run five miles as part of this training, but found that he could not keep up with his team-mates. He was referred to a physician, who noted tenderness in his thigh muscles and at the lower costal margins, but no weakness. The haemoglobin was $11.4 \mathrm{~g} / \mathrm{l}$, white blood cell coun $6600 / \mathrm{mm}^{3}$, erythrocyte sedimentation rate $42 \mathrm{~mm}$ in the first hour, and, bilirubin 16 $\mathrm{mmol} / \mathrm{l}$. Liver enzymes and alkaline phosphatase were normal. The creatine kinase (CK) level at this time was 11000 IU/ (normal < $195 \mathrm{IU} / \mathrm{l}$ ). Several days later the CK level was normal and resting muscle pain had resolved but, because of fatigue and muscle pain on exercise, he was still unable to resume training. Markers of autoimmune disease, an antibody screen for viral and other infections, and a sickle-cell test were negative. Electromyography showed myopathic features. A diagnosis of idiopathic inflammatory myopathy was considered likely. Muscle biopsy was refused.

Five weeks after the onset of the illness he was referred for advice on management. Review of the history revealed that fever, fatigue, and muscle pain had become periodic, occurring every third day. He admitted he had not taken antimalarial prophylaxis while in Ghana, believing himself immune since he had been born in that country. Physical examination was normal, but a blood film revealed parasites of Plasmodium falciparum in red blood cells.

$\mathrm{He}$ was treated with a course of quinine sulphate $600 \mathrm{mg}$ three times a day for a week with Fansidar (pyrimethamine $25 \mathrm{mg}$ with sulfadoxine $500 \mathrm{mg}$ ) three tablets on the eighth day. After completing this treatment he resumed training but, after a threemile run, his muscles ached and the blood $\mathrm{CK}$ rose to $1650 \mathrm{IU} / \mathrm{l}$, falling to $572 \mathrm{IU} / \mathrm{l}$ three days later. He returned to play as centre-forward in the first team two month later; $\mathrm{CK}$ levels at this time were normal.

Inflammatory myopathy is the commonest cause of muscle disease in adult life. In developed countries most cases are idiopathic, but a number of infections form part of the differential diagnosis. In our patient the diagnosis of falciparum malaria was suggested by the history.

Circulatory changes occur in the microvasculature in malaria, consisting of increased viscosity, obstruction of capillaries with agglutinated red blood cells and, sometimes, intravascular coagulation, ${ }^{1}$ changes that can cause skeletal muscle necrosis with myoglobinuria. ${ }^{2}$ These concepts resemble those suggested in idiopathic inflammatory myopathies. ${ }^{3}$ Exercise releases CK from damaged muscle fibres. The delayed recovery observed in our patient, who had been partially treated earlier in the course of the disease, is consistent with these mechanisms.

There were 2300 imported cases of malaria in the UK in 1991, with 12 deaths. ${ }^{4}$ The risk of infection during unprotected travel in West Africa is $2 \%$ per month. ${ }^{4}$ Falciparum malaria often presents with non-specific symptoms, of which muscle pain is a component. ${ }^{4} \mathrm{~A}$ quarter of children admitted to hospital in coma with $P$ falciparum malaria in The Gambia had a raised CK level, whereas those with mild symptoms had normal CK levels. ${ }^{5}$ Our patient was unusual in that involvement of muscle, causing muscle pain, loss of exercise tolerance, and exercise-related increase in $\mathrm{CK}$ level was the principal manifestation of malaria.

M SWASH Department of Neurology, Section of Neurological Sciences, Royal London Hospital, London E1 1BB, UK M S SCHWARTZ Department of Neurology, Atkinson Morley's Hospital, Copse Hill, Wimbledon,

Correspondence to: $\operatorname{Dr} M$ Swash

1 Miller LH, Usami S, Chien J. Alteration in the rheologic properties of Plasmodium knowlesi-infected red cells; a possible mechanism for capillary obstruction. $\mathcal{f}$ Clin Invest 1972;50:1451-5.

2 De Silva HJ, Goonetilleke AKE, Senaratna N, et al. Skeletal muscle necrosis in severe falciparum malaria. BMF 1988;296:1039.

3 Emslie-Smith AM, Engel AG. Microvascular changes in early and advanced dermatochanges in early and advanced de.
myositis. Ann Neurol 1990;27:343-56.

4 Whyast GB. Malaria, the mimic. If Med Defence Union 1992;8:54-6.

5 Miller KD, White NJ, Lott JA, et al. Biochemical evidence of muscle injury in African children with severe malaria. F Infect Dis 1989;159:139-42. whiplash syndrome"?

In an interesting study of whiplash injury, Ettlin et al" claim "possible damage to basal frontal and upper brainstem structures" evident in largely reversible "defects of attention and concentration", and by abnormal otoneurological tests (in nine of 17 patients) within two weeks of injury. This implies subtle structural damage which increases the behavioural response to pain. To explain the claimed continuation of neck pain and stiffness, other authors have inculpated, but not consistently demonstrated, subtle lesions in the cervical cord, roots, or facet joints.

The issue may, however, be clouded, unless patients with acute nerve root or cord symptoms or signs grafted onto preaccident spondylosis are excluded from whiplash syndromes. ${ }^{2}$ Recovery from acute whiplash injury is complete within three months in about $75 \%$ patients in most large published series. Chronic whiplash, how-
Subtle cerebral lesions in "chronic

ever, is contentious. ${ }^{23}$ The outstanding features are: the unexplained high incidence in women; the prolonged nature of symptoms and apparent disability without attendant objective signs; the common association with anxiety, fatigue, irritability $^{12-8}$ and, sometimes, simulated physical signs. ${ }^{1}$ Unlike almost all other sequelae of trauma, immobilisation and analgesics are often ineffective. In published series no good control group exists; most sufferers are involved in litigation.

MRI provides a refined and sensitive method of showing such putative structural lesions, ${ }^{4}$ and brainstem auditory evoked potentials (BAEP) are commonly abnormal in brainstem lesions, including vestibular pathways. I have therefore reviewed the major published findings (table), including results of Ettlin et al. ${ }^{1}$ Despite reports ${ }^{1}$ of non-specific defects of attention, concentration, and early vestibular dysfunction, the absence of demonstrated structural lesions in the brain and cervical canal and joints is the most telling, and, in my view, conclusive evidence against any theory that invokes anatomical disruptive lesions as the explanation for the continuation of symptoms. It corresponds to the absence of conventional physical and radiological signs and to the normal results of BAEP studies. $^{36}$ Davis et $a l^{9}$ have reported 14 patients, nine with acceleration hyperextension "whiplash" injuries and five injured by direct, frontal head trauma who underwent MRI within four months of injury. Five of seven patients with anterior spinal column injuries showed characteristic separation of the disk from the vertebral end plate, lesions still evident as late as nine months after injury. ${ }^{9}$ This small mixed series, however, includes major osseous and disc lesions which should be excluded by definition. Yarnell and Rossie ${ }^{6}$ in patients with severe debility 12 months after injury, conclude that: "Neurological examination, imaging and clinical electrophysiological studies were unable to localize structurally or functionally, the source of the (neuropsychological) dysfunctions".

Objective evidence shows that victims of acute whiplash injury have sustained no more than a muscular-ligamentous $\operatorname{sprain}^{7}$; therefore, unusually protracted complaints ("chronic whiplash") may demand explanations that lie outside the fields of organic and psychiatric illness,-a view possibly supported by a current publication ${ }^{10}$ claiming striking alleviation due to soft-tissue injections with water.

J M S PEARCE

1 Ettlin TM, Kischka U, Reichmann S, et al. Cerebral symptoms after whiplash injury of the neck: a prospective clinical and neuropsychological study of whiplash injury. $f$ Neurol Neurosurg Psychiatry 1992;55:943-9.

2 Pearce JMS. Whiplash injury: a reappraisal. $f$ Neurol Neurosurg Psychiatry 1989;52: 1329-31.

Table MRI of brain and cervical canal, and brainstem auditory evoked potential (BAEP) studies in whiplash injuries

\begin{tabular}{|c|c|c|c|c|c|}
\hline & Maimaris & $\begin{array}{l}\text { Van Meydam } \\
\text { et al }\end{array}$ & Yarnell and Rossie ${ }^{6}$ & Ettlin et $a^{3}$ & Total \\
\hline $\begin{array}{l}\text { No. patients } \\
\text { Abnormal MRI:brain } \\
\text { Abnormal MRI:neck }\end{array}$ & $\begin{array}{l}4 \\
\text { ND } \\
0 / 4\end{array}$ & $\begin{array}{l}15 \\
\text { ND } \\
0 / 15\end{array}$ & $\begin{array}{l}27 \\
0^{\star} / 20\end{array}$ & $\begin{array}{l}15 \\
0 / 15 \\
\end{array}$ & $\begin{array}{l}61 \\
0^{\star} / 35 \\
0 / 19\end{array}$ \\
\hline BAEP abnormal/total & ND & ND & $0 / 17$ & $0 / 14$ & $0 / 31$ \\
\hline
\end{tabular}

* 1 only mild atrophy; 1 small non-specific frontal white matter signal."

$\mathrm{ND}=$ no data. 
3 Porter KM. Neck sprains after car accidents. $B M F$ 1989;298:973-4.

4 Maimaris C. Neck sprains after car accidents. $B M \Im$ 1989;299:123.

5 Van Meydam K, Sehlen S, Schlenkhoff D, Kiricuta JC, Beyer HK. Kernspintomographische Befunde beim Halswirbelsäulentrauma. Fortschr Roengenstr 1986;145 657-60.

6 Yarnell PR, Rossie GV. Minor whiplash head injury with major debilitation. Brain Inj 1988;2/3:255-8.

7 Pearce JMS. Whiplash injury, fact or fiction Headache $O$ Curr Treat Res 1992;3:45-50.

8 Kischka U, Ettlin TM, Heim S, Schmid G. Cerebral symptoms following whiplash injury. Eur Neurol 1991;31:136-40

9 Davis SJ, Teresi LM, Bradley WG Jr, Ziemba MA, Bloze AE. Cervical spine hyperextension injuries: MR findings. Radiology sion injuries: MR

10 Byrn C, Olsson I, Falkheden L, et al. Subcutaneous sterile water injections for chronic neck and shoulder pain following whiplash injuries. Lancet 1993;341:449-52.

\section{Car toll neuropathy}

The "piriformis muscle syndrome" is an entrapment syndrome of the sciatic nerve as it passes through the greater sciatic notch. Buttock tenderness, leg pain aggravated after internal rotation of the flexed limb, and a limp are the main features of this clinical syndrome. Sciatica is reproduced upon deep digital palpation. Common causes include pelvic or buttock trauma, pelvic surgery, mass lesions, and piriformis muscle anomalies. I have seen a patient who developed the piriformis muscle syndrome after a car trip through three European countries with highway charges.

This 70-year-old, previously healthy man returned to Germany from a holiday trip to Portugal with his car. In order to pay the car toll in Spain and France he had prepared small change in the necessary currencies and put it in his left back trouser pocket. He made the 18-hour trip in one day. On the next day he complained of pain in his left buttock down the posterior thigh, which became worse during the days that followed. The pain increased with walking but not with coughing. After the exclusion of a lumbar disc prolapse by spinal CT and persisting pain, despite application of several analgesics and nonsteroidal antirheumatics, the patient was referred for neurological evaluation six weeks after the car trip.

On examination, he showed a limp, holding his left leg in mild external rotation. Both passive internal rotation and forced adduction of the affected limb by the examiner caused pain. There was piriformis tenderness on deep digital palpation. The straight-leg-rising test was negative. There were no pareses and normal reflexes, but mild atrophy of the left gluteal muscles was apparent. Although routine electroneurographic studies of the sciatic nerve and its branches revealed normal results, there was a delay of the $\mathrm{H}$-reflex on the left side when the test was performed after internal rotation of the limb. Pelvic CT excluded a mass lesion of the piriformis muscle. The patient was successfully treated by local injections with lidocaine and steroids in combination with physical therapy.

The "piriformis muscle syndrome" has been reported after prolonged sitting on a toilet seat" and as "credit-card-wallet sciatica". ${ }^{2}$ In this patient, the electrophysiologically documented syndrome $\mathrm{e}^{3}$ was caused by the coins prepared for the car toll on a trans-European car trip.

$$
\begin{array}{r}
\text { PETER BERLIT } \\
\text { Alfried Krupp Clinic, Essen, } \\
\text { Germany } 45117
\end{array}
$$

1 Taxay EP. Toilet-seat neuropathy. $N$ Engl $f$ Med 1969;280:1484

2 Lutz EG. Credit-card-wallet sciatica. $\mathcal{F} A M A$ 1978;240:738.

3 Fishman LM, Zybert PA. Electrophysiologic evidence of piriformis syndrome. Arch Phys Med Rehabil 1992;73:359-64.

"Familial paroxysmal tremor": an essential tremor variant?

The presence of symmetrical postural tremor in the hands, affecting several members of a family (familial essential tremor), is a common movement disorder, of which the clinical features are well known. ${ }^{1-3}$ We describe a patient with paroxysmal postural tremor in both hands. His mother and two of his brothers had a similar clinical picture.

A 24-year-old man, who was a good player of classic guitar, was referred to our hospital because of episodic hand tremor. $\mathrm{He}$ had no previous neurological diseases. Since the age of 18 , he had had episodes of symmetrical postural tremor limited to the hands lasting from 10 to 60 minutes, occurring once every three to six weeks. These episodes began abruptly and ended gradually. Tremor was not associated with dystonic postures or movements. Neurological examination was normal except for the presence of the postural hand tremor during the episodes. The intensity of the tremor was variable for each episode, but occasionally it interfered with writing, eating, drinking, or playing the guitar. We were unable to find any precipitating factor such as ethanol, other drugs or toxic substances, tiredness, anxiety, exercise, occupation, fasting, etc. All routine investigations, including thyroid hormones, plasma catecholamines during one episode, EEG, and cranial CT were normal. Electromyographical recording when his arms were outstretched showed a synchronous 9-10 $\mathrm{Hz}$ tremor. Because the episodes of tremor were infrequent and mild, we did not treat him with drugs.

Two of his four brothers, aged 21 and 22 years, have an episodic tremor with the same characteristics, although this is less severe and the frequency of presentation of episodes is lower, occurring since the age of 20. His mother, aged 50 years, began with an identical clinical picture in late adolescence, but the frequency and intensity of the tremor episodes decreased with the passage of time. Finally she developed, at age 48, a typical essential tremor in the hands, which responded to propranolol.

The movement disorder of our patient was a postural tremor affecting both hands. The clinical and electromyographical features of this tremor were indistinguishable from those of essential tremor, although the paroxysmal presentation of the tremor is exceptional. To our knowledge, only three cases of paroxysmal tremor have been described: two patients with paroxysmal head tremor associated with cervical dystonia $^{4}$ and one child with "rubral-like" tremor in arms and legs, and orofacial dyskinesia associated with a biopterin-synthesis defect." We propose this "familial paroxysmal tremor" as a possible variant of essential tremor.

$$
\begin{array}{r}
\text { E GARCIÁ-ALBEA } \\
\text { F J JIMÉNEZ- JIMÉNEZ } \\
\text { L AYUSO-PERALTA, } \\
\text { J TEJEIRO } \\
\text { F CABRERA-VALDIVIA } \\
\text { A VAQUERO } \\
\text { Section of Neurology, } \\
\text { Hospital Universitario "Principe de Asturias", } \\
\text { Carretera de Meco S/N, } \\
\text { E-28805 Alcalá de Henares, } \\
\text { Madrid, Spain }
\end{array}
$$

Correspondence to: Dr Garcia-Albea.

1 Martinelli P. Different clinical features of essential tremor: a 200 patient study. Acto Neurol Scand 1987;75:106-11.

2 Weiner WJ, Lang AE. Tremor. In: Weine WJ, Lang AE, eds. Movement disorders: comprehensive survey. Mount Kisco, NY: Futura, 1989; 221-56.

3 Lou HS, Jankovic J. Essential tremor: clinical correlates in 350 patients. Neurology 1991; 41:234-8.

4 Hughes AJ, Lees AJ, Marsden CD. Paroxysmal dystonic head tremor. Mov Paroxysmal dystonic

5 Factor SA, Coni RJ, Cowger M, Rosenblum EL. Paroxysmal tremor and orofacial dyskinesia secondary to a biopterin synthesis defect. Neurology 1991;41:930-2. 